Society for the Anthropology of Work • Essential Labor

\title{
Essential for Whom? Paid Domestic Work during the COVID-19 Pandemic
}

\section{Caitlin Alcorn}

Published on: Aug 13, 2020

DOI: $10.21428 / 1 \mathrm{~d} 6 \mathrm{be} 30 \mathrm{e} .52 \mathrm{~d} 1 \mathrm{fd} 78$

License: Creative Commons Attribution 4.0 International License(CC-BY 4.0). 
On March 19, 2020, the governor of the Brazilian state of Rio de Janeiro announced the state's first COVID-19 related death. Cleonice Gonçalves, a 63-year-old domestic worker, contracted the virus from her employer, who had recently returned from a trip to Italy and tested positive for the virus. Despite the diagnosis, Cleonice's employer insisted that she continue working in the woman's home. On March 15 , Cleonice started to show symptoms of the virus; just two days later she was dead.

Cleonice's death set off debates about race and class privilege in Brazil and the unequal impacts of the virus on the country's most vulnerable populations. In times of crisis, domestic work often becomes a flashpoint for discussions about social inequality in Brazil. Earlier this year, Economy Minister Paulo Guedes sparked controversy when he attempted to explain the benefits of the high exchange rate between the U.S. dollar and the Brazilian real. To make his point, Guedes argued that the previously lower exchange rate meant that "everyone was going to Disneyland, even maids were going to Disneyland" rather than traveling to domestic tourist destinations. Back in 2016, a photo of a white couple walking to an anti-government protest in Rio, followed by a black woman pushing the couple's two children in a stroller, set off similar debates.

The institution of paid domestic work has a long and complex history in Brazil, dating back to the colonial era when enslaved black women worked as servants in the homes of white slave owners. In societies "with long, unbroken histories of domestic servitude, the institution can be seen as central to understanding self and society" (Ray and Qayum 2009: 2). The domestic employment relationship represents a microcosm of the system of race, gender, and class hierarchies that characterize Brazilian society. As such, it makes sense that domestic work becomes an entry point for wider public debates, particularly in times of crisis when those hierarchies are potentially shaken or strengthened. Furthermore, it is important to note the ways in which paid domestic work has been constituted as "essential" in the Brazilian context. Employing a domestic worker has long been a means by which middle class families signal their membership in the middle classes (Goldstein 2013; Pinho 2015). The institution of paid domestic work is thus deemed essential by those who depend on it for maintaining middle-class lifestyles and reproducing racialized middle-class identities. Paradoxically, because of this role, "the system demands that domestic work be the lowest paid, affordable to even the lowest ranks of the middle classes, since it is in and of itself a distinguishing feature of middle-class life" (Goldstein 2013: 109). Particularly in periods of economic downturn, when the middle classes experience increased anxiety of losing their status, the essential role of domestic work perversely contributes to its very devaluation.

Of the more than six million domestic workers in Brazil, 92 percent are women and 60 percent are Afro-Brazilian women (IPEA 2019). Despite accounting for nearly 15 percent of total female employment, paid domestic work is plagued by low wages, long working hours, low rates of 
unionization, and high rates of abuse and informality. Long excluded from basic labor laws, domestic work has been characterized as unproductive and unskilled, misrecognized as not "real work." Brazil's colonial history and its attendant racial and gendered labor hierarchies are key to understanding the place of paid domestic work in contemporary Brazilian society (Vieira 1987; Melo 1989; Kofes 2001; Rezende and Lima 2004; Oliveira 2008; Bernardino-Costa 2011; Castro et al. 2018). Three and a half centuries of slavery enforced an association between blackness and manual labor (Pinho 2015), stigmatizing and devaluing both. Whiteness in turn became imbued with notions of superiority and authority (Rezende and Lima 2004; Pinho and Silva 2010). The white middle-class inherited "a repugnance for manual and domestic work, as well as the custom of taking for granted the ethos of servility, expecting to be 'naturally' served by those considered inferior and powerless" (Castro 1993: 20).

Today, the employment of a domestic worker remains "a defining feature of middle-class life" (Goldstein 2013: 110), a necessity for distancing oneself from the stigma of manual labor. In many ways, the institution of paid domestic work both reflects and reproduces gender, race, and class-based inequalities. In the daily performance of work deemed dirty, notions of racial and class inferiority are reinscribed on the body of the domestic worker (Pinho 2015). Her employer, in turn, can construct her own racial and class identity in opposition to that of the domestic worker who is positioned as her inferior other, more suitable to carry out the dirtiest and most labor-intensive work (Pinho 2015; RothGordon 2016).

This necessary, life-sustaining work is made precarious through processes of legal exclusion by the state and devaluation by employers. The COVID-19 pandemic has brought the depths of that precarity into sharp focus, making clear to all what the workers themselves have long known. Domestic workers have been left with few options: continue working and risk being infected with the virus, or stay home with no pay. The extent of those options are further restricted by the type of labor arrangement in which the domestic worker is engaged. A survey conducted by the market research firm Instituto Locomotiva in April 2020 shines a light on the disparities between diaristas, domestic workers who work for multiple employers with no formal contract or entitlement to basic labor protections, and mensalistas, full-time domestic workers who are entitled to a formal employment contract thanks to a constitutional amendment passed in 2013. The survey found that in response to the COVID-19 outbreak, 39 percent of employers had dismissed their diaristas with no pay. In contrast, just 13 percent of employers of mensalistas had done the same. Indeed, 48 percent of employers of mensalistas claimed to have continued paying their employee while not requiring them to come to work, while 39 percent said that their employees continued to work as normal during the pandemic.

In an op-ed published shortly after Cleonice's death, the activist, historian, and former domestic worker Preta Rara posed the question, “For whom does the life of domestic workers matter?" Her 
response: "Just for them and their families! They want our labor at all costs and have no empathy for our life." The domestic worker-employer relationship is notoriously complex and fraught with emotional ambiguities (Brites 2014). Employers often characterize domestic workers as "part of the family" rather than workers engaged in a formal employment contract (Motta 1999; Anderson 2000; Romero 2002; Gonçalves 2010). Domestic workers, too, in performing the intimate work of caring for children over the course of many years, develop family-like bonds that further complicate the employment relationship (Brites 2007). But underlying the relationship, as Preta Rara argues, is a devaluation of the labor and life of the domestic worker. The refusal on the part of many employers to grant domestic workers paid leave during the COVID-19 pandemic underscores this point.

Though domestic workers care for some of the most important aspects of their employers' lives, their own lives-outside of the time and effort they expend keeping house and home for their employersappear to be of little value. This much was clear before the pandemic. In interviews conducted as part of my dissertation research in 2018, domestic workers in the city of São Paulo described a sense of entitlement to their physical and emotional labor on the part of employers. This entitlement is often coupled with a dismissal of the workers' own social reproductive needs and responsibilities, all of the things that are necessary to make and sustain life on a daily and generational basis. Evelyn, a full-time nanny explained: “They don't think that we have a life, that we have our own children, that we have our husband, that we have our own family, that we also need time for ourselves ... They're like, 'I'm paying and you're going to stay in here and that's it,' you know?" Despite the vital role that domestic workers play in maintaining their employers' homes and caring for their families, workers' own survival (as another of my interviewees put it) is of little concern.

After Cleonice's death, children of Brazil's domestic workers launched a campaign entitled "For the Lives of Our Mothers," demanding that domestic workers be granted paid leave during the pandemic (Griffin 2020; Oliveira 2020). The petition, which as of early August has over 130,000 signatures, explains: "For years our mothers, grandmothers, aunts, cousins have dedicated their lives to other families, we are all affected by this regressive, slave-like 'labor relationship.' We had our lives marked by this context, which needs to be rethought throughout society, above all, by employers." The COVID19 pandemic is yet another manifestation of the ways in which intersecting hierarchies of race, gender, and class serve to devalue paid domestic work in Brazil and around the world. With any hope, the activism provoked by the pandemic may also spark a revaluation of that labor and respect for the lives of those who perform it.

\section{Acknowledgments}

This article is based on research supported by the National Science Foundation under Grant no. 1833330. Any opinions, findings, and conclusions or recommendations expressed in this material are those of the author and do not necessarily reflect the views of the National Science Foundation. 


\section{Author Bio}

Caitlin Alcorn is a PhD candidate in the Department of Geography at the University of Washington.

\section{Preview Image}

Courtesy of Gilbert Mercier.

\section{References}

Anderson, Bridget. 2000. Doing the Dirty Work? The Global Politics of Domestic Labour. London: Zed Books.

Bernardino-Costa, Joaze. 2011. “Destabilizing the National Hegemonic Narrative: The Decolonized Thought of Brazil's Domestic Workers' Unions." Translated by Paulo Simões. Latin American Perspectives 38(5): 33-43.

Brites, Jurema. 2007. “Afeto e desigualdade: Gênero, geração e classe entre empregadas domésticas e seus empregadores." Cadernos Pagu 29: 91-109.

2014. “Domestic Service, Affection and Inequality: Elements of Subalternity." Women's Studies International Forum 46: 63-71.

Castro, Mary Garcia. 1993. “The Alchemy Between Social Categories in the Production of Political Subjects: Class, Gender, Race and Generation in the Case of Domestic Workers' Union Leaders in Salvador-Bahia, Brazil." European Journal of Development Research 5(2): 1-22.

Maria das Graças Neves de Souza, and João Victor Marques da Silva. 2018. “Between Biography_ and History: Domestic Workers in Contemporary_Brazil." Journal of Latino/Latin American Studies 9(1): 19-34.

Goldstein, Donna. 2013. Laughter Out of Place: Race, Class, Violence, and Sexuality in a Rio Shantytown. Berkeley: University of California Press.

Gonçalves, Terezinha. 2010. “Crossroads of Empowerment: The Organisation of Women Domestic Workers in Brazil." IDS Bulletin 41(2): 62-69.

Griffin, Jo. 2020. “'For the lives of our mothers': Covid-19 Sparks Fight for Maids' Rights in Brazil.” Guardian, May 5.

Kofes, Suely. 2001. Mulher, mulheres: Identidade, diferença e desigualdade na relação entre patroas e empregadas domésticas. Campinas, Brazil: Editora da Unicamp. 
Melo, Hildete Pereira de. 1989. “Feminists and Domestic Workers in Rio de Janeiro.” In Muchachas No More: Household Workers in Latin America and the Caribbean, edited by Elsa M. Chaney and Mary Garcia Castro, 245-67. Philadelphia: Temple University Press.

Motta, Alda Britto da. 1999. "Doing Housework for Pay: Political Struggles and Legal Rights of Domestic Workers in Brazil." In Women, Development and Labor of Reproduction: Struggles and Movements, edited by Mariarosa and Giovanna F. dalla Costa, 117-33. Trenton, NJ: Africa World Press.

Oliveira, Carolina. 2020. "Filhos de empregadas domésticas lançam manifesto pelo direito à quarentena das mães." Brasil de Fato, March 20.

Oliveira, Creusa Maria. 2008. “A organização política das trabalhadoras domésticas no Brasil.” In Reflexões feministas: Sobre informalidade e trabalho doméstico, edited by Maria Betania Ávila, Milena Prado, Tereza Souza, Vera Soares, and Verônica Ferreira, 109-115. Recife, Brazil: SOS Corpo.

Pinho, Patricia de Santana. 2015. "The Dirty Body that Cleans: Representation of Domestic Workers in Brazilian Common Sense." Meridians 13(1): 103-128. , and Elizabeth Silva. 2010. "Domestic Relations in Brazil: Legacies and Horizons." Latin American Research Review 45(2): 90-113.

Ray, Raka, and Seemin Qayum. 2009. Cultures of Servitude: Modernity, Domesticity, and Class in India. Stanford, CA: Stanford University Press.

Rezende, Cláudia Barcellos, and Márcia Lima. 2004. "Linking Gender, Class and Race in Brazil." Social Identities 10(6): 757-73.

Romero, Mary. 2002. Maid in the USA: 10th Anniversary Edition. New York: Routledge.

Roth-Gordon, Jennifer. 2016. Race and the Brazilian Body: Blackness, Whiteness, and Everyday Language in Rio de Janeiro. Oakland: University of California Press.

Vieira, Celma Rose. 1987. “Negra, mulher e doméstica: Considerações sobre as relações sociais no emprego doméstico." Estudos Afro-Asidticos 14: 141-58. 